\title{
Life History Characteristics of a Small Cardinalfish, Ostorbinchus rubrimacula (Percoidei: Apogonidae), from Koro, Fiji ${ }^{1}$
}

\author{
Ken Longenecker ${ }^{2,3}$ and Ross Langston ${ }^{2}$
}

\begin{abstract}
We describe aspects of the life history of the small cardinalfish Ostorbinchus rubrimacula from a single, large collection taken at Koro, Fiji. We determined size at maturity and batch fecundity, examined otolith microstructure to construct a vonBertalanffy growth curve, described a length-weight relationship, and performed a dietary analysis. Ostorbinchus rubrimacula is a gonochore that matures at $35 \mathrm{~mm}$ standard length (SL). Batch fecundity is related to body size by the equation: eggs spawned $=0.0013(\mathrm{SL})^{3.8685}$. Assuming each otolith ring corresponds to 1 day in age, the oldest individual in our collection lived 274 days. Growth is described by the equation: $\mathrm{SL}=40.84\left[1-e^{-0.014 \text { (age in days }-22.45}\right]$. Total body mass $(\mathrm{mg})=4.806 \cdot 10^{-6}(\mathrm{SL})^{3.5163}$. Ostorbinchus rubrimacula feeds primarily on harpacticoid copepods, but isopods (mostly gnathidean) and polychaetes were also important dietary components.
\end{abstract}

Perhaps because they are usually unimportant in food or aquarium fisheries, the life histories of small, cryptic reef fishes are largely unknown. However this is often the most abundant and speciose group of fishes found on coral reefs. As reef-fish ecologists

${ }^{1}$ This paper is funded in part by a grant/cooperative agreement from the National Oceanic and Atmospheric Administration, Project No. R/FM-8, which is sponsored by the University of Hawai'i Sea Grant College Program, SOEST, under Institutional Grant No. NA16RG2254 from NOAA Office of Sea Grant, Department of Commerce. The views expressed herein are those of the authors and do not necessarily reflect the views of NOAA or any of its subagencies. UNIHI-SEAGRANT-JC03-09. This work was also supported by NSF (DEB 0102745 to D. W. Greenfield and J. E. Randall) and NIH (RR03061 to the University of Hawai'i Biological Electron Microscope Facility). This is contribution 2005-009 of the Pacific Biological Survey and Hawaii Institute of Marine Biology contribution No. 1202. Manuscript accepted 2 June 2005.

${ }^{2}$ Hawai'i Institute of Marine Biology, P.O. Box 1346, Kāne'ohe, Hawai'i 96744 and Department of Zoology, University of Hawai'i, 2538 The Mall, Honolulu, Hawai'i 96822.

${ }^{3}$ Current address: Bishop Museum, 1525 Bernice Street, Honolulu, Hawai'i 96817 (e-mail: klongenecker@ bishopmuseum.org).

Pacific Science (2006), vol. 60, no. 2:225-233

(C) 2006 by University of Hawai'i Press

All rights reserved attempt to generalize about factors that structure reef-fish communities, it becomes increasingly important to understand the life history characteristics of all members of the coral-reef fish community. The high numerical abundances, small body sizes, small home ranges, and presumptive short life spans make small cryptic fishes ideal candidates for field experiments evaluating the importance of ecological processes by examining their effects on population demography. The first step in any such study requires a description of basic demographic parameters of the model species.

The family Apogonidae (cardinalfishes) contains over 200 species from 22 genera (Nelson 1994). Apogonids typically rank second or third of all reef fish families in abundance and species diversity (Bellwood 1996). Most cardinalfishes feed on invertebrates found on coral reefs or open sand during the night (Chave 1978) and repeatedly return to the same shelter site on the reef during the day (Marnane 2000), usually in multispecific aggregations in caves or branching corals (Greenfield and Johnson 1990). Thus these fishes may influence trophic pathways by concentrating energy and nutrients, in the form of fish biomass and waste products, to predictable locations on coral reefs (Marnane 2000).

We describe the reproductive patterns, age and growth, and diet of a population of a 
recently described cardinalfish species, Ostorbinchus rubrimacula (Randall \& Kulbicki 1998), collected during a fish survey of the Fiji Islands. The taxonomic status of apogonid genera is currently in flux. Fraser (1972) recognized 10 subgenera within Apogon. Bergman (2004) elevated these to genera and replaced Nectamia with Ostorbinchus. We follow Bergman (2004) and Randall (2005) in recognizing Apogon rubrimacula as a junior synonym of Ostorbinchus rubrimacula. This is a small-bodied (to $47 \mathrm{~mm}$ standard length [SL]) species often seen in small aggregations in the Solomon Islands, New Caledonia, Loyalty Islands, Great Barrier Reef, Papua New Guinea, and the Fiji Islands. It is morphologically similar to O. cyanosoma and is difficult to distinguish from that species in preservative. Ostorbinchus rubrimacula differs from O. cyanosoma with the presence of a single red spot at the midbase of the caudal fin, a higher number of gill rakers, and apparently a smaller maximum size (Randall and Kulbicki 1998).

\section{MATERIALS AND METHODS}

\section{Collection}

We collected all specimens at 0845 hours on 12 November 2002 from a small, isolated coral outcrop surrounded by fine-grained sand in $3 \mathrm{~m}$ of water at the north end of Koro Island $\left(17^{\circ} 15.01^{\prime} \mathrm{S}, 179^{\circ} 21.21^{\prime} \mathrm{E}\right)$ during a survey of the marine fishes of the Fiji Islands. We released $1.5 \mathrm{~kg}$ of powdered Derris root (Prentox Rotenone Fish Toxicant Powder, Prentiss, Floral Park, New York) mixed with 1.48 liters of dishwashing liquid (Ivory, Procter and Gamble, Cincinnati, Ohio) over approximately $21 \mathrm{~m}^{2}$. We collected fish using SCUBA and hand nets for 1 hr after the Derris solution was released.

We stored specimens on ice until processing. We selected 48 individuals, representing the size range of fish collected, for age-andgrowth and size-at-maturity analyses. We measured the SL of these specimens to the nearest $0.5 \mathrm{~mm}$, removed their saggittae, and fixed their gonads in formalin. All other conspecifics were fixed whole in formalin.

\section{Reproduction}

We dehydrated formalin-preserved gonads in a graded ethanol series, embedded them in glycol methacrylate (JB-4 Embedding Kit, Electron Microscopy Sciences, Hatfield, Pennsylvania), and sectioned them at 2-5 $\mu \mathrm{m}$ on a microtome (Sorvall Products, Newtown, Connecticut) fitted with a glass knife. We affixed these sections to glass microscope slides, stained them in toluidine blue, and examined them for evidence of reproductive maturity. We classified ovaries according to Wallace and Sellman (1981) and testes according to Nagahama (1983). We considered female fish mature with the onset of vitellogenesis, and males mature when the testes contained free spermatozoa. We report size at sexual maturity as the size at which a regression equation (three-parameter, sigmoidal) of percentage mature individuals in each $1-\mathrm{mm}$ size class versus standard length indicates $50 \%$ of individuals are mature.

We estimated batch fecundity using the oocyte size-frequency method (MacGregor 1957, Hunter et al. 1985), assuming that the largest mode of yolked, nonhydrated oocytes formed the next spawning batch. In O. rubrimacula, this mode consisted of oocytes with a diameter of $425 \mu \mathrm{m}$ or greater. We used a two-parameter power equation to describe the relationship between batch fecundity and standard length.

\section{Age and Growth}

We used digital calipers to measure the long axis (rostrum to postrostrum [nomenclature of Secor et al. 1992]) of saggittae or saccular otoliths (Figure 1a). We prepared a single, transverse section of each saggitta by mounting the otolith, lateral side down, on a glass microscope slide in thermoplastic glue (Crystal Bond No. 509, Electron Microscopy Sciences, Hatfield, Pennsylvania) and then removing a section containing the core using a low-speed saw (Isomet 11-1180, Beuhler, Lake Bluff, Illinois). We affixed this section to a glass microscope slide, cut side down, with thermoplastic glue; ground to the core using a series of 600 - and 1,300-grit sand- 


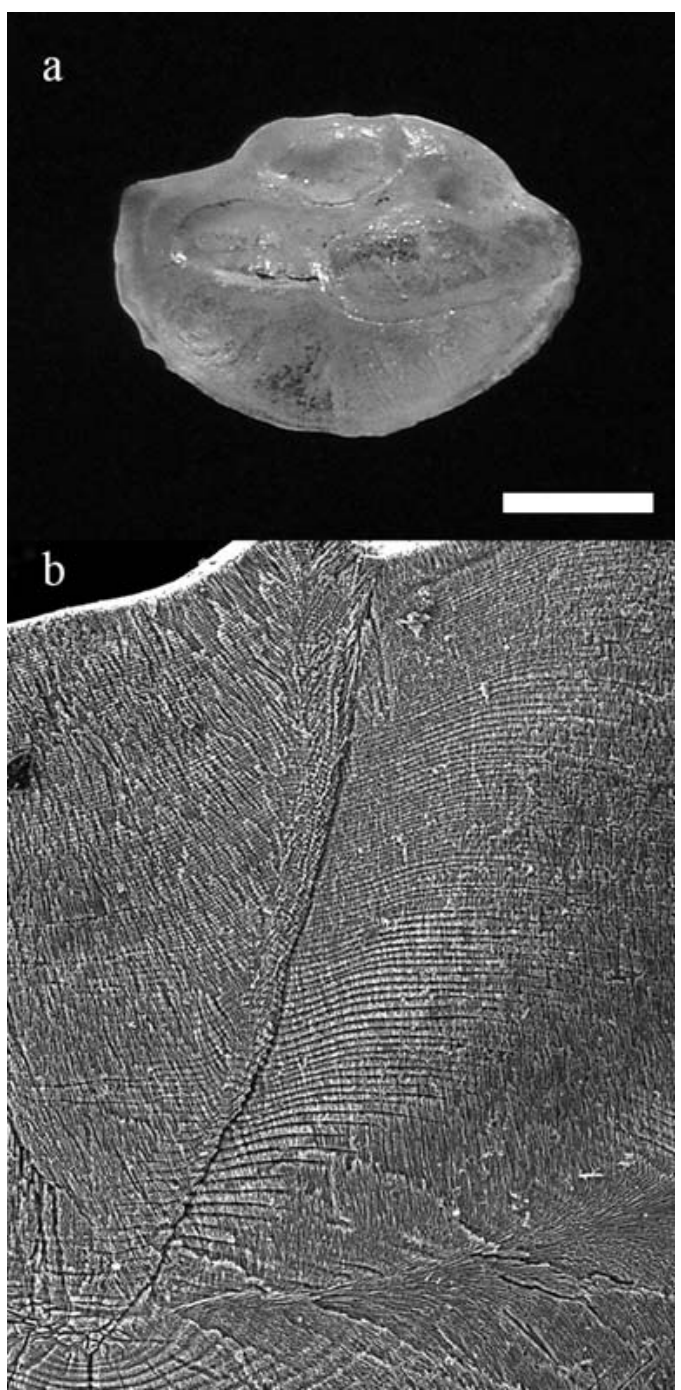

FIgURE 1. Sagitta (saccular otolith) of O. rubrimacula: (a) medial aspect of a whole sagitta from a $39-\mathrm{mm}(\mathrm{SL})$ specimen; scale bar $=1 \mathrm{~mm}$; (b) scanning electron micrograph of a prepared section from a $28-\mathrm{mm}$ (SL) specimen. We counted 128 increments.

paper; then polished the section with 0.3 - and $0.05-\mu \mathrm{m}$ alumina slurry on felt. We etched the polished surface with a $2.5 \%$ solution of unbuffered EDTA for 3-5 min, then rinsed with deionized water. We dissolved the thermoplastic glue with acetone and mounted prepared otolith sections on aluminum stubs. We coated these sections with a gold- palladium film in a sputtercoater (Hummer II, Technics, Alexandria, Virginia), and viewed them on a field emission scanning electron microscope (Hitachi S-800, Hitachi High Technologies America, Schaumburg, Illinois). We used Photoshop 7.0 (Adobe Systems, San Jose, California) to examine digital images of the otolith sections (see Figure 1b).

We calculated the average standard length and average estimated age for each apparent 10-day age group. We used these grouped data and followed the methods outlined in Everhart and Youngs (1992) to construct a vonBertalanffy growth curve. Briefly, we estimated $L_{\infty}$ (asymptotic length, or the length at which growth rate is theoretically zero) using a Ford-Walford plot of standard length data, and $K$ (rate of growth toward $L_{\infty}$ ) and $t_{0}$ were estimated from a plot of $\ln \left(L_{\infty}-L_{t}\right)$ versus estimated age $\left(t_{0}=\right.$ the age when length is theoretically zero; $L_{t}=$ the length at age $t$ ). We examined the relationship between fish and otolith length by linear regression analysis. We measured total body mass (to $0.1 \mathrm{~g}$ ) of specimens not used for age and growth analysis and described a length-weight relationship using a two-parameter power regression.

\section{Diet}

We randomly selected specimens from the portion of the collection not used for age and growth analysis until we found 20 individuals with stomachs containing food. We identified, to gross taxonomic levels, all prey contained in the stomach and used a squash plate modified from Ross (1974) to estimate the volume of each prey type found in a stomach. Briefly, our squash-plate technique consisted of comparing the diameter of a prey item compressed between two microscope slides (held a constant distance apart by coverslips) with a regression equation for a known volume of water and its diameter in the same apparatus.

We report the Pinkas et al. (1971) Index of Relative Importance (IRI) for each prey type, where:

$$
\mathrm{IRI}=(\% N+\% V) \% F O
$$

Here, $\% N$ (percentage number) is the per- 


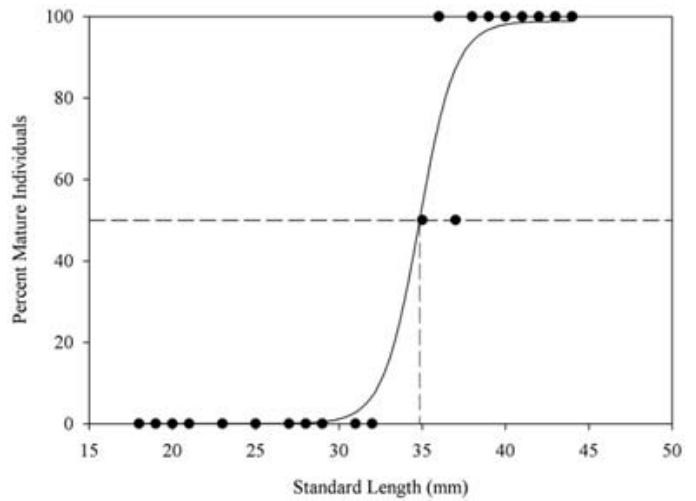

Figure 2. Size at maturity for O. rubrimacula $(n=33)$. Fifty percent of individuals in the $35-\mathrm{mm}$ size class were mature.

centage of prey items of a given type relative to the total number found, $\% V$ (percentage volume) is the percentage volume of the prey type relative to the total volume of prey found, and $\% F O$ (percentage frequency of occurrence) is the percentage of sampled fish containing the prey type.

\section{RESULTS}

\section{Reproduction}

We were able to extract gonads from 33 of the 48 individuals used for age-and-growth analysis (undeveloped gonads were likely to be removed with the head portion), and we performed histological examination on these. Fifty percent of $O$. rubrimacula individuals in the $35-\mathrm{mm}$ size class were mature (Figure 2). This is also the smallest size class in which we found mature individuals. All $38-\mathrm{mm}$ or larger specimens were mature. There was no evidence that males and females mature at different sizes. A power function [batch fecundity (no. of eggs) $=0.0013(\mathrm{SL})^{3.8685}$ ] relates batch fecundity to standard length (Figure 3a).

We found no evidence of sequential hermaphroditism in O. rubrimacula. There was not a significant sex-based bimodal size distribution. Further, classic histological signs of sex change (Sadovy and Shapiro 1987) were absent: Testes lacked a lumen or brown bodies, and ovaries did not contain spermatogenic tissue. Ostorbinchus rubrimacula is apparently a gonochore.

\section{Age and Growth}

We were unable to validate otolith increment periodicity. However, our unpublished work with Hawaiian cardinalfishes demonstrates that increments are formed daily. Marnane (2001) also validated daily increment formation in Australian cardinalfishes. Thus we assume that each ring represents 1 day in age. The growth of O. rubrimacula can be described by the vonBertalanffy curve, standard length (SL) in $\mathrm{mm}=40.84[1$ $\left.e^{-0.014(\text { age in days - 22.45) }}\right]$ (Figure $3 b$ ). We did not detect a difference between male and female growth.

The vonBertalanffy growth curve suggests that $35-\mathrm{mm}$ SL individuals (our estimated size at maturity [see Figure 2]) are approximately 161 days old. The estimated age for the oldest fish in this population was 274 days, suggesting that reproductive life is approximately 16 weeks or $42 \%$ of total life span.

The relationship between otolith length and SL (Figure 3c) can be described with a linear equation $[\mathrm{SL}=-1.72+13.20$ (otolith length in $\mathrm{mm}$ )]. A power function [total weight in $\left.\mathrm{mg}=4.086 \cdot 10^{-6}(\mathrm{SL} \text { in } \mathrm{mm})^{3.5163}\right]$ describes the relationship between SL and total body mass (Figure $3 d$ ).

Diet

We examined 21 specimens ranging from 24 to $42 \mathrm{~mm} \mathrm{SL}$ (mean of 31.4 ). One (4.8\%) of these stomachs was empty. The following results are for identifiable prey from 20 stomachs containing food. We identified $93 \%$ of prey, by volume; all unidentified items were crustacean fragments.

The diet of $O$. rubrimacula consists of small, benthic invertebrates and fishes (Figure 4). The degree of digestion suggests that most prey were taken earlier in the day (conceivably at night given the nocturnal foraging habits of most apogonids). Many of the specimens consumed large numbers of harpacti- 

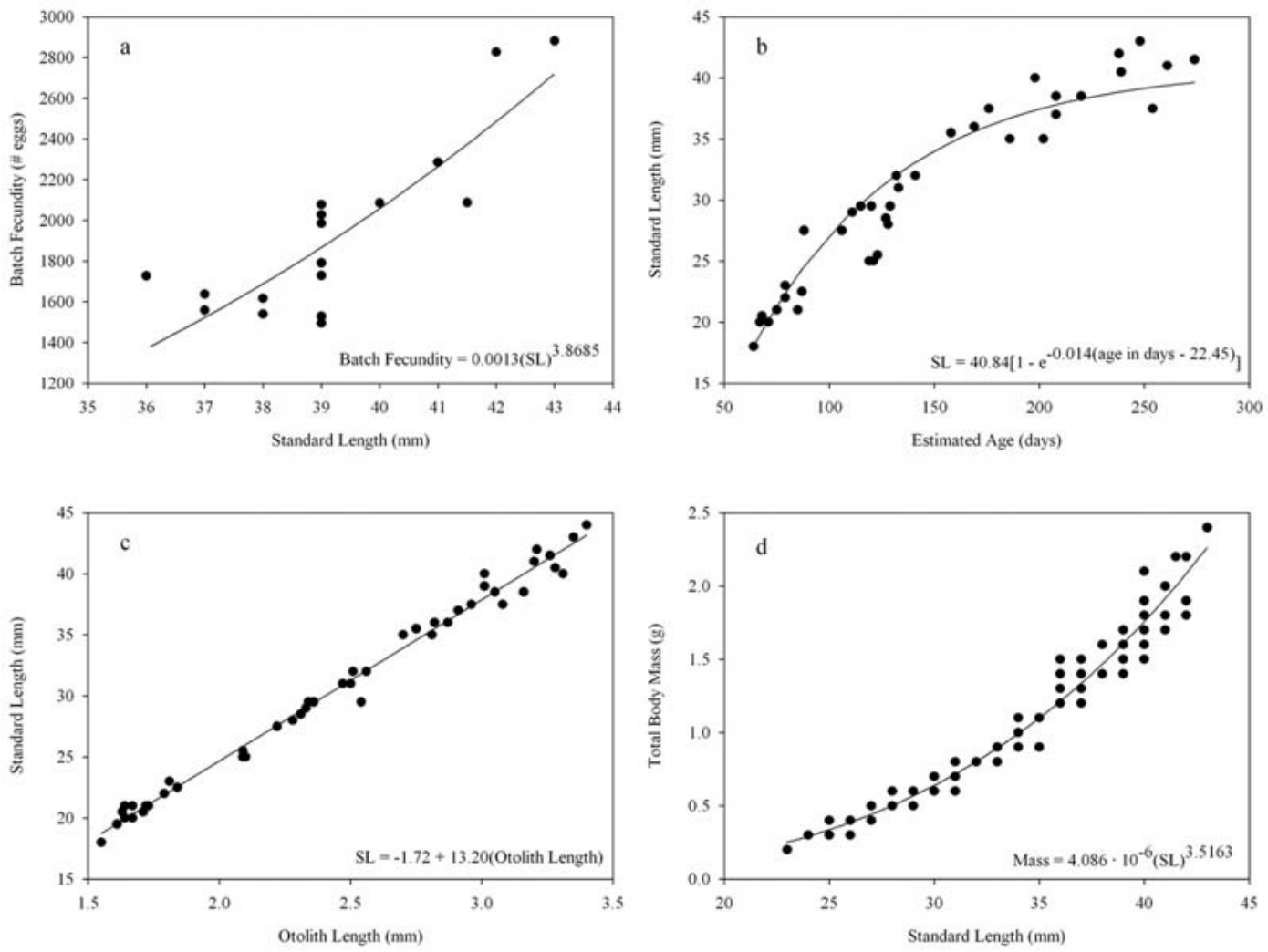

FIGURE 3. Relationships between SL (mm) and various life-history parameters for O. rubrimacula: $(a)$ SL versus batch fecundity; $R^{2}=0.734, n=17$; (b) estimated age versus SL and a vonBertalanffy growth curve; $R^{2}=0.903, n=39$; (c) otolith length versus SL; $R^{2}=0.989, n=48$; $(d)$ SL versus total body mass; $R^{2}=0.966, n=109$.

coid copepods and isopods. The majority of isopods were gnathidean. Also frequently consumed were a few, large polychaetes. Fish eggs (or developing embryos) were found in two specimens and were the sole stomach content in those specimens. Occasionally a single, large (relative to other prey items) fish was eaten. Stomachs often contained one or a few small tanaids, ostracods, amphipods and/or crab larvae. Mysids, alpheid shrimp, and gastropods were also eaten but appear to be unimportant in the diet of these O. rubrimacula specimens.

\section{DISCUSSION}

Despite their small size and the apparent ubiquity of parental care, cardinalfishes vary widely in the number and size of eggs produced. Some species produce large batches of relatively small eggs, whereas others produce a small number of large eggs. The strategy employed does not appear to be related to body size; both extremes are found in large- and small-bodied species. For example, large-bodied Apogon rueppellii (to $90 \mathrm{~mm}$ SL) and small-bodied Pterapogon kauderni (to 50 $\mathrm{mm}$ SL) both produce relatively small batches (40 and 210, respectively) of large eggs (2.4$3 \mathrm{~mm}$ ) (Chrystal et al. 1985, Vagelli 1999), whereas small-bodied Ostorbinchus rubrimacula (this study) falls at the other extreme, producing thousands (Figure $3 a$ ) of small eggs. This strategy is shared with the largebodied Paroncheilus affinis, which produces 1,900-21,000 eggs of $0.7-\mathrm{mm}$ diameter (Lav- 


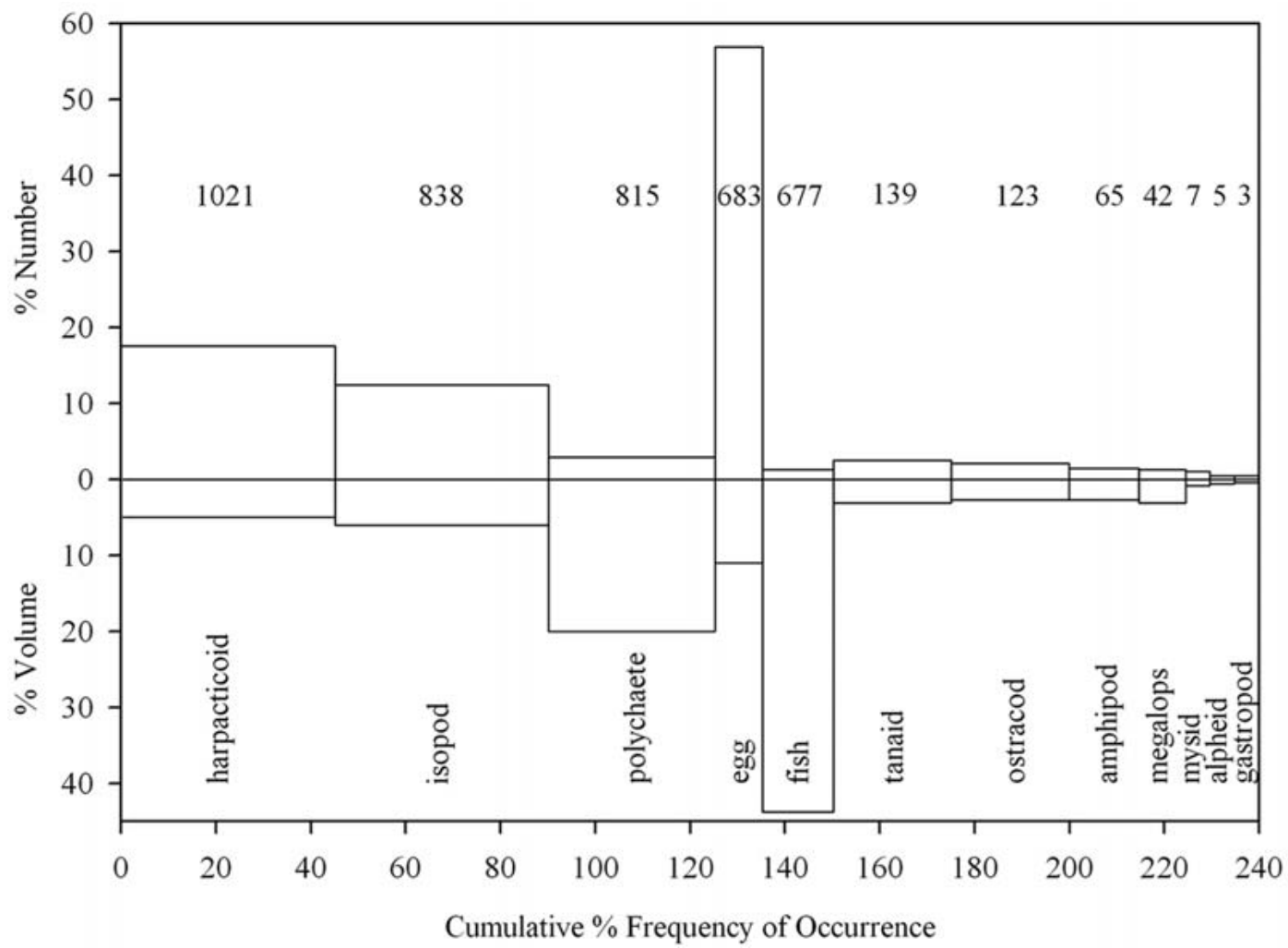

FIgURE 4. Diet of O. rubrimacula. Numbers above each prey type are absolute IRI values. Twenty individuals (all containing food) ate a combined total of 277 items with a cumulative volume of $79.89 \mu \mathrm{l}$.

ett Smith et al. 1971). These reproductive strategies may represent trade-offs between survivorship and dispersal ability. Larvae hatching from large-diameter eggs are themselves larger and more precocious, with higher individual survivorship (Duarte and Alcaraz 1989) and often a reduced planktonic duration (Thresher et al. 1989). For example, larvae of $P$. kauderni hatch at a large size (5-6 $\mathrm{mm} \mathrm{SL}$ ) and have no planktonic period (Vagelli 1999). The species is endemic to a single island in Indonesia. In contrast, species that maximize egg number typically give rise to many small larvae that spend a longer time in the plankton, disperse widely, and presumably experience low individual survivorship. Based on our fecundity data, O. rubrimacula may exhibit the latter strategy.

The growth curve we constructed for $O$. rubrimacula assumes that otolith increment formation is daily. Although we did not validate increment periodicity, daily ring formation has been validated in apogonids of similar maximum size in two Hawaiian species by R. C. Langston (pers. obs.) and in two Australian species, including closely related (Randall and Kulbicki 1998) O. cyanosoma (Marnane 2001). Our use of the vonBertalanffy equation is appropriate because the relationship between $\ln \left(L_{\infty}-L_{t}\right)$ and apparent age is linear (see Everhart and Youngs 1992).

Age and growth analysis of four species by Marnane (2001) suggests a positive, linear relationship between maximum size and longevity: larger species (90-100 mm SL) lived approximately $2.5 \mathrm{yr}$, whereas smaller species (50-60 $\mathrm{mm} \mathrm{SL}$ ) lived approximately $1 \mathrm{yr}$. Further supporting this suggestion are the results of Chrystal et al. (1985), who found that 
Apogon rueppellii grows to $164 \mathrm{~mm}$ and lives for $2 \mathrm{yr}$, and Mees et al. (1999), who found that 60- to 80-mm Sphaeramia orbicularis lived 11-15 months. We performed work on the smallest cardinalfish studied to date, and our results agree with those observations: Relative to other cardinalfishes, O. rubrimacula is short-lived (up to $3 / 4 \mathrm{yr}$ ).

The regressions of otolith length versus SL and SL versus total body mass will be useful to describe the importance of O. rubrimacula in the diets of other fishes. Detailed description of piscivore diets is often difficult because fish remains are digested beyond the point of identification or accurate size measurement. Otoliths have been used as taxonomic indicators in paleontology, archaeology, and dietary analyses (Dye and Longenecker 2004). We did not make an extensive collection of otoliths from Fijian fishes; however we have included an image of a sagitta from $O$. rubrimacula in the hope that it will be useful in future studies (Figure 1a). The length (Figure $3 c$ ) and weight (Figure $3 d$ ) regressions can be used to estimate the size of the fish that produced the otoliths (Echeverria 1987, Gamboa 1991).

Most cardinalfishes are thought to be nocturnal feeders (Hiatt and Strasburg 1960, Marnane 2002). The advanced degree of digestion of most prey items found in the stomachs suggests that $O$. rubrimacula feeds nocturnally. Also, the gut of O. rubrimacula is darkly pigmented. Fishelson et al. (1997) suggested that this "black gut phenomenon" is a characteristic of nocturnally foraging cardinalfishes and may serve to conceal bioluminescent prey. Hobson (1965) reported that most apogonids feed on free-swimming or epibenthic organisms, and Marnane (2002) further suggested that they are important predators on demersal plankton, benthic invertebrates that migrate into the water column at night (Alldredge and King 1977). Certainly, most prey items consumed by $O$. rubrimacula are components of demersal plankton, but not all individuals of these invertebrate populations migrate into the water column at night (Mendoza 1982, Sudo and Azeta 1992), and some prey (gastropods) are not likely to be found in the water column.
Because we did not observe feeding behavior, we cannot state whether O. rubrimacula is a demersal or planktonic feeder.

Like many cardinalfish species (Chave 1978, Chrystal et al. 1985, Suto and Azeta 1992, Marnane 2002), O. rubrimacula preys primarily on crustaceans. Polychaetes and fishes were occasionally eaten and because of their large size (relative to the crustaceans consumed) were also important. Chrystal et al. (1985) found that harpacticoids were more important in the diet of small Apogon rueppellii, whereas fishes and polychaetes became more important in the diet of larger individuals. We did not find an ontogenetic reduction in harpacticoid consumption or an increase in fish and/or polychaete consumption. However, the smallest individual in our collection was $23 \mathrm{~mm}$ SL. Because size at settlement has not been reported for O. rubrimacula it is unclear whether our collection contains the full size range of postsettlement individuals. Three scenarios are possible: (1) our sampling missed new recruits owing to their small size, (2) there was no recent recruitment to the population we sampled, or (3) O. rubrimacula may settle at a large size $(20 \mathrm{~mm}+)$ as reported for several cardinalfishes (Thresher 1984, Leis and Rennis 2000). Based on our experience with the collecting technique, we think scenario 1 is unlikely. Derris is a nonselective ichthyocide useful in sampling small-bodied fishes over large size ranges, and we routinely collected gobies and blennies $<10 \mathrm{~mm}$ SL. Thus we believe our collection is an accurate representation of the size range of the sample population. Scenarios 2 and 3 are equally plausible but cannot be evaluated without information on recruitment size and seasonality in $\mathrm{O}$. $r u$ brimacula.

Two individuals ate eggs. We assumed these eggs were from conspecifics because they looked exactly like mature eggs found in the ovaries of females and in the buccal cavities of mouth-brooding males. This egg consumption can be interpreted in at least two ways: (1) it represents filial cannibalism. Kume et al. (2000) suggested that partial filial cannibalism helps males maintain physical condition during the "nonfeeding" brooding 
period. The individuals with eggs in their stomach did not contain any other food; however we do not know whether these were male; (2) eggs were ingested during a stress response to Derris. We observed cardinalfishes ejecting egg masses from their mouths after we applied Derris solution to the sample area. It is possible that hungry individuals took advantage of a suddenly abundant food source before dying.

\section{ACKNOWLEDGMENTS}

We thank D. W. Greenfield for donating specimens. We are grateful to the captain and crew of Moku Makua Hine for their help and to the people of Fiji (especially Koro Island) for their hospitality and for allowing us to work in their waters.

\section{Literature Cited}

Alldredge, A. L., and J. M. King. 1977. Distribution, abundance, and substrate preferences of demersal reef zooplankton at Lizard Island Lagoon, Great Barrier Reef. Mar. Biol. (Berl.) 41:317-333.

Bellwood, D. R. 1996. The Eocene fishes of Monte Bolca: The earliest coral reef fish assemblage. Coral Reefs 15:11-19.

Bergman, L. M. 2004. The cephalic lateralis system of cardinalfishes (Perciformes: Apogonidae) and its application to the taxonomy and systematics of the family. Ph.D. diss., University of Hawai'i at Mānoa, Honolulu.

Chave, E. H. 1978. General ecology of six species of Hawaiian cardinalfishes. Pac. Sci. 32:245-270.

Chrystal, P. J., I. C. Potter, N. R. Loneragan, and C. P. Holt. 1985. Age structure, growth rates, movement patterns and feeding in an estuarine population of the cardinalfish Apogon rueppellii. Mar. Biol. (Berl.) 85:185-197.

Duarte, C. M., and M. Alcaraz. 1989. To produce many small or few large eggs: A sizeindependent reproductive tactic in fish. Oecologia (Berl.) 80:401-404.

Dye, T. S., and K. Longenecker. 2004. Manual of Hawaiian fish identification based on the skeletal reference collection of Alan C. Ziegler and including otoliths. Society for Hawaiian Archaeology. Special Publication 1.

Echeverria, T. W. 1987. Relationship of otolith length to total length in rockfishes from northern and central California. Fish. Bull. 85:383-386.

Everhart, W., and W. Youngs. 1992. Principles of fishery science. Comstock, Ithaca.

Fishelson, L., M. Goren, and O. Gon. 1997. Black gut phenomenon in cardinal fishes (Apogonidae, Teleostei). Mar. Ecol. Prog. Ser. 161:295-298.

Fraser, T. H. 1972. Comparative osteology of the shallow water cardinalfishes (Perciformes: Apogonidae) with references to the systematics and evolution of the family. Ichthyol. Bull. J. L. B. Smith Inst. Ichthyol. 34:1-105.

Gamboa, D. A. 1991. Otolith size versus weight and body-length relationships for eleven fish species of Baja California, Mexico. Fish. Bull. 89:701-706.

Greenfield, D. W., and R. K. Johnson. 1990. Heterogeneity in habitat choice in cardinalfish community structure. Copeia 1990:1107-1114.

Hiatt, R. W., and D. W. Strasburg. 1960. Ecological relationships of the fish fauna on coral reefs of the Marshall Islands. Ecol. Monogr. 30:65-127.

Hobson, E. S. 1965. Diurnal-nocturnal activity of some inshore fishes in the Gulf of California. Copeia 1965:291-302.

Hunter, J. R., N. C. H. Lo, and R. J. H. Leong. 1985. Batch fecundity in multiple spawning fishes. NOAA Tech. Rep. NMFS 36:67-77.

Kume, G., A. Yamaguchi, and T. Taniuchi. 2000. Filial cannibalism in the paternal mouthbrooding cardinalfish Apogon lineatus: Egg production by the female as the nutrition source for the mouthbrooding male. Environ. Biol. Fishes 58:233-236.

Lavett Smith, C., E. H. Atz, and J. C. Tyler. 1971. Aspects of oral brooding in the cardinalfish Cheilodipterus affinis Poey (Apogonidae). Am. Mus. Novit. 2456:1-11.

Leis, J. M., and D. S. Rennis. 2000. Apogonidae (Cardinalfishes). Pages 273-279 in 
J. M. Leis and B. W. Carson-Ewart, eds. The larvae of Indo-Pacific coastal fishes. Fauna Malesiana Handbook 2.

MacGregor, J. S. 1957. Fecundity of the Pacific sardine (Sardinops caerulea). Fish. Bull. $57: 427-449$.

Marnane, M. J. 2000. Site fidelity and homing behaviour in coral reef cardinalfishes. J. Fish. Biol. 57:1590-1600.

. 2001. The trophic role of cardinalfishes (Family Apogonidae) on coral reefs. Ph.D. diss., James Cook University, Townsville, Australia.

2002. Diet and nocturnal foraging in cardinalfishes (Apogonidae) at One Tree Reef, Great Barrier Reef, Australia. Mar. Ecol. Prog. Ser. 231:261-268.

Mees, J., G. U. Mwamsojo, and E. O. Wakwabi. 1999. Aspects of the biology and feeding ecology of the orbiculate cardinalfish Sphaeramia orbicularis (Cuvier, 1828) (Teleostei: Apogonidae) in a Kenyan mangrove forest. Biol. Jaarb. Dodonaea 66:134-145.

Mendoza, J. A. 1982. Some aspects of the autecology of Leptochelia dubia (Kroyer, 1842) (Tanaidacea). Crustaceana (Leiden) 43:225-240.

Nagahama, Y. 1983. The functional morphology of teleost gonads. Pages 223-275 in W. S. Hoar, D. J. Randall, and E. M. Donaldson, eds. Fish physiology IXA. Academic Press, New York.

Nelson, J. S. 1994. Fishes of the world, 3rd ed. John Wiley and Sons, New York.

Pinkas, L., M. Oliphant, and I. L. K. Iverson. 1971. Food habits of albacore, bluefin tuna and bonito in Californian waters. Calif. Fish Game 152:1-105.

Randall, J. E. 2005. Reef and shore fishes of the South Pacific. University of Hawai' $i$ Press, Honolulu.
Randall, J. E., and M. Kulbicki. 1998. Two new cardinalfishes (Perciformes: Apogonidae) of the Apogon cyanosoma complex from the western Pacific, with notes on the status of $A$. wassinki Bleeker. Rev. Fr. Aquariol. 25 (1-2): 31-39.

Ross, S. 1974. Resource partitioning in searobins (Pisces: Triglidae) on the West Florida shelf, PhD diss., University of South Florida, Tampa.

Sadovy, Y., and D. Y. Shapiro. 1987. Criteria for the diagnosis of hermaphroditism in fishes. Copeia 1987:135-156.

Secor, D., J. Dean, and E. H. Laban. 1992. Otolith removal and preparation for microstructural examination. Pages 19-57 in D. K. Stevenson and S. E. Campana, eds. Otolith microstructure examination and analysis. Can. Spec. Publ. Fish. Aquat. Sci. 117.

Sudo, H., and M. Azeta. 1992. Selective predation on mature male Byblis japonicus (Amphipoda: Gammaridea) by the barface cardinalfish Apogon semilineatus. Mar. Biol. (Berl.) 114:21-217.

Thresher, R. E. 1984. Reproduction in reef fishes. T.F.H. Publications, Neptune City, New Jersey.

Thresher, R. E., P. L. Collin, and L. J. Bell. 1989. Planktonic duration, distribution, and population structure of western and central Pacific damselfishes (Pomacentridae). Copeia 1999:420-434.

Vagelli, A. 1999. The reproductive biology and early ontogeny of the mouthbrooding Banggai cardinalfish, Pterapogon kauderni (Perciformes, Apogonidae). Environ. Biol. Fish. 56:79-92.

Wallace, R. A., and K. Sellman. 1981. Cellular and dynamic aspects of oocyte growth and maturation in teleosts. Am. Zool. 21:325-343. 
